\title{
Willem Fourie
}

\section{CAN CHRISTIAN ETHICS BE USED TO ENGAGE BUSINESS? A (SOUTH) AFRICAN CONSIDERATION}

\begin{abstract}
Business enterprises are in a position to exert a significant influence on society - particularly in the context of developing countries. Businesses no longer simply influence shareholders, employees and customers, but also play a role in strengthening (or weakening) political institutions and contributing to the wellbeing of other stakeholders. The result is that business enterprises are increasingly accountable to a growing number of stakeholders. In this article the possibility of utilising Christian ethics to engage business is investigated. The question is whether it is at all possible for the church to address the business world by applying its particular ethical resources, and - should this be possible - what form such engagements could take.
\end{abstract}

\section{INTRODUCTION}

Christian ethics in its literal sense can be viewed from at least two perspectives. From one perspective the qualifier "Christian" can refer to ethics practised by Christians. From another perspective it can be understood as ethics meant to be applicable to Christians, in this sense referring to ethics for Christians. These two perspectives introduce questions about the audiences that may legitimately be addressed by Christian ethics. This article is based on the interplay between the two perspectives. It will be argued that it is possible to use the ethics practised by Christians to address the business world.

Willem Fourie, Department of Dogmatics and Christian Ethics, Faculty of Theology, University of Pretoria, Private bag X20, Hatfield, Pretoria, 0028, South Africa. Email: willem.fourie@up.ac.za. 
The context in which this question is asked - a post-colonial developing country with democratic institutions still in the process of maturing - it is not simply of academic importance. Businesses have a significant role to play in the development of developing countries as they have an impact on more people than simply their shareholders, employees and customers (Institute of Directors of Southern Africa 2009:11), and they have opportunities to exert political leverage - both in strengthening (Moon, Crane \& Matten 2005) and undermining democracy (Koenig-Archibugi 2004). Intuitively it seems as if the church ought to be able to engage these important societal actors. This article will examine the ethical role of this particular intuition more closely.

We start by asking who actually practises Christian ethics, and consequently whether Christian ethics are meant only for the church. The article does not intend to provide exhaustive theological arguments on these two issues. They are rather regarded as giving descriptive and historical hints on how to view the practitioners of, and audiences for, Christian ethics. The two sections dealing with these issues will provide us with working definitions of the practitioners and audiences of Christian ethics and will form the basis for considering how the practitioners of Christian ethics can engage the business world by examining documents formulated by the World Alliance of Reformed Churches in Kitwe and Accra and the Institute of Directors of Southern Africa.

\section{TOWARDS WORKING DEFINITIONS}

\subsection{The practitioners of Christian ethics}

Key moments in the history of Christianity can assist us to a significant extent in formulating a working definition of the practitioners of Christian ethics.

The early church was faced with the challenge of applying its particular theological resources to reach an understanding of what constitutes acceptable behaviour within the Christian community (Wogaman 1993:2336). Ethics and identity were intertwined as the early church increasingly positioned itself as distinct from Judaism. As the church outgrew its sectarian origins, the perceived ethics of its members were increasingly experienced as being at odds with what was accepted in society (Ferguson 1993:556-562). For the early Christians, not worshipping the emperor and practising syncretism were not simply theologically-based choices, but deeply ethical decisions (Gonzalez 1984:14-15). Internally the Christian community was also faced with serious challenges. The connection 
between theology, ecclesiology and ethics was translated in some groups to moral lethargy, whilst other developed at times extreme forms of moral rigour (Evans 2008:29-34).

Galerius' change in policy towards Christians in the Roman Empire in 311 (A.D.), the Edict of Milan of 313 (A.D.) and Constantine's increasing benevolence towards the Christian community changed the mode in which the church applied its teachings (Evans 2008:36). The connection between religious and political identities became closer, so much so that "official theologies" - addressed not only to the church but also to broader society - started to develop (Gonzalez 1984:129-135).

As the church developed into an important societal institution with its own standing before the law, and consequently increasingly prescribing and legitimating Christian conduct, the tension between public and church ethics intensified (cf. Ginther 2008:48). The church began to find itself in a continuous process of applying its teachings to the often rapidly changing architecture of societal power relations. The German and Swiss Reformations of the sixteenth century signify both its influence on and reaction to changing societal relations. Luther's emphatic defence of the freedom of a Christian - and the related responsibility towards others - is an important example of both a recommitment to theological sources and their concrete and contextual application in a very specific socio-cultural and political context (cf. Jüngel 1988). Calvin both strengthened the normative role of the church in Christian ethics - by famously confirming that the church exists where the Word is duly preached and the sacraments are duly administered - and broadened its reach - by explicating God's law as also the basis for public order (Mudge 2008:613-614).

Since the key moments outlined above, many changes have taken place within and around the church. But even amidst a plurality of Christian churches, which are at times bitterly divided and operative on a number of levels, it still seems to be the case that the church understands itself as the primary practitioner of Christian ethics. In our view this plurality does not contradict the fact that the church remains the primary practitioner of Christian ethics, and continues to express this deeply Christian conviction. The South African theologian Dirk Smit identifies - descriptively - six forms of the church, which helps us to engage with this plurality and to connect present-day experience with the hints described above. Centuries of differentiation in society and the church have led to societal institutions and indeed societies with much higher forms of coordination and complexity than the case was centuries ago. This necessarily means that the church now functions on a number of different levels. According to Smit, the church exists as worshipping communities, local congregations, 
denominations, ecumenical bodies, voluntary organisations and individual believers (Smit 1996:21-22). In our view this differentiation helps us to understand the multiple sites of expression of the church as the locations where the church continues to be the primary practitioner of Christian ethics.

But this raises a second question. Does the church as primary practitioner of Christian ethics, even in a plurality of ways, imply that Christian ethics are also meant to be addressed exclusively to the church?

\subsection{The audience(s) for Christian ethics}

For some the distinction between the practitioners and audiences of Christian ethics may seem artificial. It may seem as if it is impossible to think of an audience of Christian ethics other than the church. In this article some significant - some might feel dissenting - traditions within the church are identified as reminders that another view is possible. These traditions may assist us in formulating a working definition of the audience(s) for Christian ethics. It is indeed the case that some traditions within Christianity have consistently maintained the conviction that any understanding of what constitutes meaningful human existence should be addressed to society as a whole and not simply the church. Indeed, our discussion of the church's role in the practice of Christian ethics has already alluded to subtle changes that have taken place in the perception of the addressees of Christian ethics. Possibly two of the clearest examples are the (related) traditions of Roman Catholic social teaching and Protestant social ethics.

The origins of modern Roman Catholic social teaching can be found in an explicit church document: Pope Leo XIII's encyclical Rerum Novarum, promulgated in 1891 (Barrera 1999:287). In this encyclical the issue of a just society - and not simply a just church - is addressed in order to search for an "opportune remedy" for "the misery and wretchedness pressing so unjustly on the majority of the working class" (Rerum Novarum, Article 3). It is fairly clear that the audience of this document - in a primary sense those who are called on to respond and in a secondary sense those whose lives are meant to be influenced - is not necessarily the same as the community within which the document was written. A number of documents followed, including Quadragesimo Anno to commemorate the $40^{\text {th }}$ anniversary of Rerum Novarum and responding to the economic crisis of 1929; Mit brennender Sorge in 1937 to respond to the political situation in Germany at the time; Pope John XXIII's Pacem in Terris on the challenge of peace in a time of nuclear proliferation; and the significant pastoral constitution Gaudium et Spes of the Second Vatican Council covering a range of 
themes. This differentiation between practitioner and audiences is present in all of these documents. Pope Benedict XVI promulgated the most recent encyclical, entitled Caritas in Veritate, in 2009. This document continues to express Roman Catholic social teaching for the perceived benefit of the whole of society.

The situation of the working-class poor at the end of the nineteenth century that gave rise to Roman Catholic social teaching is generally viewed as also the genesis of Protestant social ethics (Jäger 1981:20). New forms of societal and personal uncertainty, poverty and changed power relations brought about by industrialisation created the need for new forms of ethical reflection. Especially socialist Protestant theologians in Germany responded to this challenge, with Leonhard Ragaz and Hermann Kutter being amongst the better known among them (Jäger 1981:19). These theorists were united in their rejection of the implicit independence and Eigengesetzlichkeit of societal spheres - especially of the economic sphere (Huber 1985:57). In the German context - where arguably the most important initial work in social ethics was done - the critique of the supposed independence of societal spheres was supplemented by detecting the legitimate (God-willed) orders (Ordnungen) present in society. Social structures such as the state, marriage and society became the theme of social ethics (Wendland 1961:19), and continued a tradition of addressing groups (and the wellbeing of these groups) outside the church.

In recent years the practitioners of social ethics and the social locations of their implementation have expanded immensely. Social ethics is now practised within the different forms of the church in developed and developing contexts for a range of non-church audiences. Reihs et al. develop ten theses that characterise Protestant social ethics (Reihs et al. 2007:11). Together these ten theses illustrate the social ethical conviction that Christian ethics is not always addressed only to the church. Indeed, the identity of Christian social ethics is formed by God's gracious justification (thesis 1), making Christians God's custodians (thesis 7), who are to advocate for a just society (thesis 4 ) in which all people have the same opportunities (thesis 6).

When viewed from the perspective of Christian social ethics, it is clear that Christian ethics may well be practised exclusively by the church, but they are certainly not meant exclusively for the church. In terms of our argument this means that Christian ethics theoretically can be used to engage the business world. However, the theoretical possibility that Christian ethics can be used to engage business does not address the somewhat more concrete question of how this may be done. The following section will investigate two ways in which Christian ethics may be used to 
engage the business world. We start by considering a reactive engagement with business and conclude the article by considering the possibility of constructive engagement. The aim of the next section is mostly to describe, rather than to prescribe, and therefore these categories are treated in a descriptive and not in a normative way.

\section{CHRISTIAN ETHICS AND BUSINESS}

\subsection{Responding to business?}

In his seminal 1987 Stob lectures James Gustafson recognises prophetic discourse as an important form of Christian moral discourse. In terms of Gustafson's characterisation, this reactive mode consists of two dimensions. It communicates in the form of moral indictments, such as "the word of the Lord proclaimed against the moral evil and apostasy of the world and societies" (Gustafson 1988:8). It is a passionate message aimed at uncovering what it perceives to be the root of evil and courageously denounces this evil. It does not simply make analytical statements, but uses complex and emotive language (Gustafson 1988:12). However, this reactive mode does not only denounce. In reaction to the situation it also

portrays an alluring vision of the future, of possibilities for life in the world in which the forms of strife and suffering we all experience are overcome (Gustafson 1988:13).

This mode clearly has both reactive as well as proactive - or visionary - dimensions.

In our understanding, prophetic reactions seem more often than not to emphasise its reactive dimension. The Kitwe Declaration (1995) and Accra Confession (2004) of the World Alliance of Reformed Churches are important examples of such a reactive engagement with business and may be used to distil some shared characteristics of such a reactive engagement.

In Kitwe the experience of economic injustice - particularly the "systematic exclusion of Africa from the world economy" (WARC 1995: "Seeing", Article 2) - led to the drafting of the Kitwe Declaration (Smit 2008). The church is accordingly compelled to engage with business enterprises, systems and even governments in a unilateral and passionate manner. The freedom the church has in determining the form of the engagement is balanced by the role of business enterprises and systems in determining the subject of the engagement. Concrete realities such as "the almost 
untouchable structures of production, distribution and consumption of material goods and services" (WARC 1995, "Seeing", Article 4) and multinational corporations that

usurp the democratic will of most of the people in Africa by coercing our governments to remove desperately needed protection from fragile enterprises (WARC 1995, "Seeing", Article 6)

play a determining role in the subject of the engagement.

Of course, already identifying the concrete realities that need to be addressed gives those that initiate an engagement some interpretative influence. This is further made clear when the "global market economy" is deemed "sacralized" and "elevated to an imperial throne" (WARC 1995, "Judging", Article 2). It is "idolatrous and dehumanizing" (WARC 1995, "Judging", Article 3) and "usurps the sovereignty of God" (WARC 1995, "Judging", Article 2). The current situation should consequently be addressed by "alternative economic practice", which is guided by "the needs of human beings in the form of the preferential protection of the poor, and respect for nature" (WARC 1995, "Acting", Article 2).

The substance - or in this case judgment - of the engagement cannot be understood without taking note of the location from which it is initiated. The economic exploitation and the resultant powerlessness of Africans (WARC 1995, "Seeing", Articles 4 and 7) and the appropriation of political power (WARC 1995, "Seeing", Article 6) and cultural impoverishment (WARC 1995, "Seeing", Article 5) brought about by multinational companies serve to describe the context of this engagement. The experience of powerlessness is central to the form and substance of this reactive engagement

Nearly a decade and a few declarations later the Accra Confession was drafted in a similarly reactive mode. The confession understands itself as a response to the unjust global economic system as the root cause of massive threats to human life and non-human forms of life on earth:

The root causes of massive threats to life are above all the product of an unjust economic system defended and protected by political and military might. Economic systems are a matter of life or death (WARC 2004, Article 6).

The concrete starting point of the confession is the "neo-liberal ideology" (WARC 2004, Article 14) that claims sovereignty over life and is therefore idolatry (WARC 2004, Article 10). This system promotes policies of limitless growth (WARC 2004, Articles 8 and 23), rampant consumerism and competitive greed and selfishness (WARC 2004, Article 29). The 
church - and implicitly the majority of the world's inhabitants - is located in a position of powerlessness in relation to the agents driving this unjust system. These agents are identified as "[t]he United States of America and its allies, together with international finance and trade institutions (International Monetary Fund, World Bank, World Trade Organization)" who use "political, economic, or military alliances to protect and advance the interest of capital owners" (WARC 2004, Article 13). The confession addresses churches' perceived position of powerlessness by also confessing the "complicity and guilt" of those who initiate interaction, particularly those who "consciously or unconsciously benefit from the current neoliberal economic global system", those who have "become captivated by the culture of consumerism" and those who misuse creation and fail to play a role as "stewards and companions" (WARC 2004, Article 34).

Articles 17 to 36 of the Accra Confession continue the rather reactive tone of the engagement by consistently connecting articles of faith with descriptions and judgments of realities. Because God is "sovereign over all creation" (WARC 2004, Article 18), for example, the "current world economic order imposed by global neoliberal capitalism" and indeed all economic systems "which defy God's covenant by excluding the poor, the vulnerable and the whole of creation from the fullness of life" are rejected (WARC 2004, Article 19). Or God's covenant with "all of creation" (WARC 2004, Article 20)

forms the basis for the rejection of

the culture of rampant consumerism and the competitive greed and selfishness of the neoliberal global market system, or any other system, which claims there is no alternative (WARC 2004, Article 21).

A particular interplay between three elements characterises a reactive application of prophetic discourse. Firstly, practitioners of Christian ethics initiate the engagement. Christian ethics therefore determine the form of this mode of engagement as a certain state of affairs usually compels the church to engage the business world in a decidedly unilateral manner. The subject of the engagement, secondly, is to a large extent formed by business itself. The church reacts to a situation brought about by business, which means that the church's reaction is materially dependent on business. Thirdly, the perceived location of the different parties is significant. A reactive engagement is typically possible where the church perceives itself as located outside the spheres of influence of the respective business or even economic systems. A reactive engagement is based on the assumption that the church is a spectator much more than a participant. 
Some observers may feel that the above characterisation of the Kitwe Declaration and the Accra Confession seems somewhat one-sided. To be sure, both documents also contain visionary dimensions. In its last section Kitwe declares that life is affirmed against death and that it refuses to let go of "a dream of a just society" as God is "the God of life, of creation, of care, of hope" (WARC 1995, "Acting", Article 6). In the Accra Declaration statements of faith that precede the rejection clauses similarly have a visionary component to them, as does the concluding section on the process of "covenanting for justice" (WARC 2004, Articles 37-42). However, one cannot help but notice that visionary sections are much shorter, much less specific, particularly on the actors and actions that can assist in rectifying the situation.

\subsection{Constructive engagement with business?}

In our understanding, a reactive engagement with the business world is certainly of great importance, but not the only option available to the church. It should also be possible for the church to engage constructively, in the sense of co-creating solutions. This way of engaging business is directly linked to a shift in the influence of business enterprises and consequently how they view their surrounding communities.

The past decades have seen significant changes in the influence of business enterprises, to the extent that some even speak of the "new constitution of commerce" (Institute of Directors of Southern Africa 2009:8). Already in the 1950s corporations were no longer large and professionally managed with shares widely held (Vogel 2005:20). Companies were not necessarily owned any longer by individuals or families, but rather by mostly institutional shareholders and managed by professional managers (Vogel 2005:22). These companies in which ownership and control have become separated have in a sense become the drivers of economic globalisation.

The changes in governance structure are closely related to a substantial increase in financial resources and political leverage that has put business in a new position of power with regard to political institutions and societies. Business is no longer solely dependent on decisions made by democratically elected political leaders and their bureaucracies. Business enterprises - in particular those operative in many different countries - have the power to make decisions - even when understood as purely financial, practical or organisational - that impact on not simply employees, customers or shareholders, but also the general public of a 
certain territory. Advances and applications in information technology and biological sciences add to the influence of business.

This changed influence of business enterprises seems to have shifted their view of their responsibility towards society, and has created new opportunities for churches to engage business. One of the most important recent global examples of this shift is the document Vision 2050: The new agenda for business released by the World Business Council for Sustainable Development (WBCSD 2011). Vision 2050 is meant to address three questions: what a sustainable world should look like, how such a world can be realised and the role business can play in realising a sustainable world.

Vision 2050 consists of two sections. The first brief section is a description of the characteristics of a world in 2050 where all 9 billion inhabitants "live well, and within the limits of the planet" (WBCSD 2011:6). The second, and more extensive section outlines the path necessary to reach the vision formulated in the first section. The "pathway to 2050" consists of nine elements. What makes this pathway significant for Christian ethicists is the fact that the first element that needs to be addressed, according to Vision 2050, is "people's values". The document recognises that unsustainable patterns of consumption are driven by destructive values in business and society. This is all the more significant when one takes into consideration that the document was initiated and written solely by multinational companies. These companies view Vision 2050 - and particularly the discussion on values - as an invitation to "all stakeholders - business, government and civil society" to "join the exploration and effort" to contribute to a more humane world (WBCSD [s.a.]). Even though one might question the motives behind this document, it is clear that it expresses a fundamental flow in global power relations and a new openness to a broad range of participants to engage in constructive dialogue.

In South Africa the third King Report on corporate governance (2009) (King III), published by the Institute of Directors of Southern Africa, similarly describes these shifting power relations and openness to constructive engagement (Institute of Directors of Southern Africa 2011:11). According to King III, business enterprises should not only take into account the interests of shareholders assumed to be in touch with societal realities, but also the "legitimate interests and expectations of stakeholders other than shareholders" (Institute of Directors of Southern Africa 2011:12). This document forms part of a broader shift in corporate governance, which acknowledges that all business enterprises have responsibilities towards all 
entities and individuals that can reasonably be expected to be significantly affected by the organization's activities, products and/ or services (GRI 2006:10).

It further acknowledges that stakeholders other than shareholders, customers and employees can often be expected to "affect the ability of the organization to successfully implement its strategies and achieve its objectives" (GRI 2006:10) and exert a significant influence on the medium- and long-term sustainability of a business enterprise. Although the interests of the societies within which business enterprises operate are taken seriously only to the extent that they serve the best interests of the company (Institute of Directors of Southern Africa 2011:12), this shift is at least an indication of a change in the perception of the stakeholders toward whom business enterprises should be accountable.

In King III business enterprises are viewed as corporate citizens that do not simply have the responsibility of building "sustainable business", but should do business "ethically" by considering "the short- and longterm impacts of the strategy on the economy, society and the natural environment" by taking into account "the company's impact on internal and external stakeholders" (Institute of Directors of Southern Africa 2011:19). The report therefore recommends that businesses establish "mechanisms and processes that support stakeholders in constructive engagement with the company" (Institute of Directors of Southern Africa 2011:47) and communicate in a "transparent and effective" manner in order to build and maintain their "trust and confidence" (Institute of Directors of Southern Africa 2011:48).

This shift seems to provide increased opportunities to practitioners of Christian ethics - in our understanding, the different forms of the church - to explore constructive modes of engaging with business. As the shift to a stakeholder inclusive approach is still relatively recent, the form and subject of these engagements still need to be refined and in many cases even established. This may well be one of the reasons why it is still virtually impossible to find church documents that engage business in a cooperative manner. Churches may even cooperate in setting up structures that will allow inclusive access to discussions and the relevant information, and promote responsiveness to the concerns of stakeholders (Steffek \& Kissling 2008:10-12). In addition, the church has a extremely important role to play in defining issues that businesses need to take into account, but about which they do not have the expertise. This includes complex issues such as morality, constructive values and dialogue between different religious and cultural groups. Here the church has an extremely important potential role to play. 
These developments locate the church not as a powerless adversary but as a competent dialogue partner. Even though the form and subject of possible constructive interactions may eventually be the prerogative of business enterprises, the church would theoretically be placed in a position to significantly influence the substance of these interactions. Engaging in constructive engagements does, of course, not mean that the church should give legitimacy to destructive business practices. It much rather means that the church has the opportunity to critically engage in attempts aimed at addressing the issues that documents such as the Kitwe Declaration and the Accra Confession are able to recognise.

\section{CONCLUSION: BETWEEN BEING IGNORED AND CO-OPTED}

This article investigated the possibility of engaging with business by using Christian ethics. By investigating some resources within the history of the church in a descriptive way, we found that - although the church can certainly be understood as the primary practitioner of Christian ethics - the church need not be understood as its only addressee. As the important traditions of social teaching and social ethics direct Christian ethics to audiences much broader than the church, we concluded that, theoretically, business could also be engaged. We subsequently developed two ways in which this engagement can take place, namely in reactive and cooperative modes.

Both these modes have their own dangers. Possibly the greatest danger of a reactive mode of engagement is that it may be to simply ignore such a contribution. Even if the analysis of a specific problem is exceptionally insightful, and delivered with passion, there is little guarantee that the addressees will be listening. Its potential irrelevance can be attributed to a number of factors. The form in which such an engagement takes place, for example, can estrange rather than engage business. It can be expressed in a way that is inaccessible to the intended addressees. And even when the form and content of the engagement are accessible, it may happen that the platforms where they are articulated are not open to those they mean to engage.

In our view a constructive engagement runs the risk of the church being co-opted by businesses and used to protect their interests. As we have indicated, this mode puts business in the position of both determining the subject and the form of the cooperative engagement. The practitioners of Christian ethics are therefore faced with the challenge to use their status as partners - and not simply adversaries - to make a contribution that is 
at the same time distinctive and constructive. This is no uncomplicated task, as it requires of the church to strike a balance between its particular sources, their application in a specific situation and the possibility of faithful compromise.

\section{BIBLIOGRAPHY}

BARRERA, A.

1999. The evolution of social ethics: Using economic history to understand economic ethics. Journal of Religious Ethics 27(2):285-304.

Evans, G.R.

2008. The Church in the early Christian centuries: Ecclesiological consolidation. In: G. Mannion and L. S. Mudge (eds), The Routledge Companion to the Christian Church (New York, NY/Abingdon: Routledge), pp. 28-47.

FERGuson, E. 1993. Backgrounds of Early Christianity, 2nd ed. Grand Rapids, Ml: Wm B Eerdmans.

GinTHER, J.R.

2008. The church in medieval theology. In: G. Mannion and L. S. Mudge (eds), The Routledge Companion to the Christian Church (New York, NY/Abingdon: Routledge), pp. 48-62.

Global Reporting Initiative. 2006. Sustainability Reporting Guidelines. Amsterdam: Global Reporting Initiative.

GonZALEZ, J.L.

1984. The Story of Christianity: The Early Church to the Dawn of the Reformation. New York, NY: HarperCollins.

Gustafson, J.M.

1988. Varieties of Moral Discourse: Prophetic, Narrative, Ethical and Policy. Grand Rapids, MI: Calvin College and Seminary.

HUBER, W.

1985. Folgen christlicher Freiheit, 2nd ed. Neukirchen-Vluyn: Neukirchener Verlag.

Institute of Directors of Southern Africa.

2009. King Code of Governance for South Africa. Johannesburg: Institute of Directors of Southern Africa.

JÄGER, A.

1981. Sozialethik als Schwerpunkt theologischer Ethik. In: A. Wildermuth and A. Jäger (eds), Gerechtigkeit. Themen der Sozialethik (Tübingen: JCB Mohr Siebeck, 1981), pp. 17-30. 
JÜNGEL, E.

1988. The Freedom of a Christian: Luther's Significance for Contemporary Theology, trans. Roy A. Harrisville. Minneapolis, MN: Augsburg.

KoENIG-ARCHIBUGI, M.

2004. Transnational corporations and public accountability. Government and Opposition 39:234-259.

Moon, J., Crane, A. and Matten, D.

2005. Can corporations be citizens? Corporate citizenship as metaphor for business participation in society. Business Ethics Quarterly 15:429-453.

MUDGE, L.S.

2008. Ecclesiology and ethics in the Western Church. In: G. Mannion and L. S. Mudge (eds), The Routledge Companion to the Christian Church (New York, NYI Abingdon: Routledge), pp. 607-622.

Pope Leo XIII 1891. Rerum Novarum: Encyclical of Pope Leo XIII on Capital and Labor.

Reihs, S., Wegner, G., Bedford-Strohm, H., Jähnichen, T., and Reuter, H.-R. 2007. Kontinuität und Umbruch im deutschen Wirtschafts- und Sozialmodell. Jahrbuch Sozialer Protestantismus I. Gütersloh: Gütersloher Verlagshaus.

SMIT, D.J.

1996. Oor die kerk as 'n unieke samelewingsverband. Tydskrif vir die Geesteswetenskappe 36:119-129.

SMIT, D.J.

2008. Challenges for Reformed Churches in Africa: A Contemporary Narrative. International Journal for the Study of the Christian Church 8:319-336.

Steffek J. And Kissuing, C.

2008. Emergent patterns of civil society participation in global and European governance. In: J. Steffek, C. Kissling \& P. Nanz (eds), Civil Society Participation in European and Global Governance: A Cure for the Democratic Deficit? (Basingstoke: Palgrave Macmillan), pp. 1-29.

Vogel, D.

2005. Is there a market for virtue? The business case for corporate social responsibility. California Management Review 47:19-45.

WENDLAND, H.-D.

1961. Über den gegenwärtigen Stand der Sozialethik. In: H.-D. Wendland (ed.), Sozialethik im Umbruch der Gesellschaft (Göttingen: Vandenhoeck \& Ruprecht), pp. $15-30$.

Wogaman, J.P.

1993. Christian Ethics: A Historical Introduction. Louisville, KY: Westminster John Knox. 
World Alliance of Reformed Churches.

1995. Reformed Faith and Economic Justice. Kitwe, October 1995. [Online.] Retrieved from http://warc.ch/pc/rfej/03.html [3 April 2012].

World Alliance of Reformed Churches.

2004. Covenanting for Justice in the Economy and the Earth. Accra, August 2004. [Online.] Retrieved from http://warc.jalb.de/warcajsp/side.jsp?news_ id $=1157 \&$ navi $=45$ [3 April 2012].

World Business Council for Sustainable Development. 2011. Vision 2050: The new agenda for business. Geneva: WBCSD

World Business Council for Sustainable Development. [s.a.] About the WBCSD. [Online.] Retrieved from http://www.wbcsd.org/ templates/TemplateWBCSD5/layout.asp?type=p\&Menuld=NjA\&doOpen=1\&Cli ckMenu=LeftMenu [3 April 2012].

Keywords

Christian ethics

Business ethics

Developing countries

Africa
Sleutelwoorde

Christelike etiek

Besigheidsetiek

Ontwikkelende lande

Afrika 